\title{
A Comparative Study of Nostalgia in the Poetry of Abdel Muti Hijazi and Nima Yushij
}

\author{
Nasser Ghasemi Rozveh \\ Department of Arabic Language and Literature, Faculty of Foreign Languages, University of Tehran, Iran \\ Zeynolabedin Faramarzi \\ Department of Theology, Faculty of Humanities, Gonbad Kavous University, Iran
}

\begin{abstract}
Nostalgia is one of the known subjects in psychology which is in direct relation with memory and recollection. Nostalgia is a longing for good old days and a comparison between past and present. That is why longing for and remembering the past would cause sorrow and grief. What causes sorrow in human beings is their separation from their ideal place, their social, political and cultural situation and in general their undesirable current conditions in life. It can be said that this unconscious behavior is a common feeling among the human beings. The nostalgia is one of the most significant subjects in modern Persian and Arabic poetry. Nima Yushij and Abdel Muti Hijazi are two of those poets that repeatedly utilized the theme of longing for blissful days of the past and remembering them in their poems. Their situation in life, keen intellect and sentiment and their familiarity with many poets and scholars are the motivation that aroused this strong feeling of nostalgia. This study accordingly to study the sources for the theme of sorrow and longing for the past in the poetry of these two we known poets.
\end{abstract}

Index Terms—nostalgia, poem, Yushij, Abdel Muti Hijazi, comparative literature

\section{INTRODUCTION}

The word nostalgia is the combination of the Greek words "Nostos" meaning a return home and "Algos" meaning pain. Oxford dictionary of English defines nostalgia as a form of heartache caused by a long term separation from home. So in this compound two words of pain and return are of utmost importance. In short nostalgia can be defined as a bitter sweet inner feeling toward things, people or places in the past. This word was first coined and used by one Johannes Hofer, a Swiss doctor, to describe the mental state of two of his patients. One of them was a student from Bern that came to Basel and the other a servant, both of them were cured after returning home to their families. From psychopathological view point nostalgia is a dream of the glorious past, a past that no longer exist and can't be rebuilt. According to Sharifian (2008) when people face hardship in their life or when they get old they seek ways to run away from their problems or wish for the return of their glorious past. But in literature nostalgia normally happens in the unconscious of the author or poet and so becomes a trademark

Nostalgia, memorandum, monuments or woe can be defined in short as a bitter sweet inner feeling toward things, people and places in the past. Another definition for nostalgia is a wistful longing for home. Oxford dictionary of English defined nostalgia as home-sickness. In the literature of the romantic period in France, in the works of Hugo, Balzac and Baudelaire nostalgia takes various meaning. In the works of Hugo it means the burning pain of exile, in the works of Baudelaire it is longing for strange lands, things lost and finally in the works of Sartre it means longing or yearning for nothingness. The cause for nostalgia can be listed as such: losing a family member or a beloved that makes you cry or sing an elegy (that brings a feeling of homesickness itself), exile or imprisonment, yearning for past that causes complaint about present, because the poet had a happy life in the past, emigration, remembering memories of childhood and youth and so on, problems of old age and thought of death, also other psychological and mental factors. Yushij and Abdel Muti Hijazi as two well-known poets of modern Persian ad Arabic literature dedicated parts of their poems to nostalgia because of their social and persona conditions in life. Here the goal of this study is to show how nostalgia is pictured in the poems of these two poet.

Yushij and Hijazi never lost hope even in the bleakest and hardest of social situations and they followed the same path in their poetical life even in the face of all those scorns insults. Hamidian (2004) states that the poetry of Yushij that his reaction to present situations it is one of these two: one is a dynamic spirit and hope for a change, in a place that people's conformity is in the horizon or an immediate future and the other one is a grave notions although an open minded one away from complete hopelessness, with an ever pondering on the reasons behind current situations or ways to get out of it, right in the heart of social oppression.

Because this study is based on theories in French comparative literature, first the conditions of research based on these theories must apply. There are two principles in the French theories for conducting a comparative study between two works or literary movement: A) there must be a linguistic differences between the two works or movements. Those two works or movement, Azimi (2003) observes, should be able to effect or affect each other and there should be a 
historical relation between them. In this article the examples in the works of these two poets have been compared concerning personal memories under the title of nostalgia of homesickness" including feeling of homesickness, utopian literature and childhood and death.

\section{Romantic Movement and Nostalgia}

One of the key subjects in Romantic Movement that highly expresses nostalgia is scape and the world tour. Frustration with the current situation and time and a desire to get away, a call to a historical or geographical journey, a real tour or one in the realm of imagination are some of characteristics of Romantic works (Seyed Hosseini, 1987). In these historical journeys the author's imagination soar toward divine and glorious days of middle ages and renaissance that based on Friedrich Schlegel, as put, "was the era of heroes and love and fairytale that created the Romanticism" (Lowy\& Sayre, 2001, p.132). In addition to imaginary journeys a romantic writer goes on real journeys as well and reflects on his memories of the journey through his work. In their journeys romantic writers hope for a glorious place in the end. The goal of a romantic writer is to find the ultimate beauty. This nostalgia for that "Paradise Lost" often includes a search for something long lost. Based on the young Lokag the Golden Age of Romanticism is not just belonged to the past, it is a goal and everyman's responsibility is to reach this goal. Another form of nostalgia in the Romantic Movement is the issue of fall from heaven and eternal spirit. In this case the poet feels that he is far away from his true self and lives in a strange land. Schlegel the famous German poet of Romantic Movement describes this feeling as "the soul under the willow tree crying in exile. The soul the house of spirituality, lives alone, away from his ideal place and his motherland in this world. In pre-Islamic era in Iran Manicheans, according to Dastgheyb (1994), believe that our soul is a tiny light trapped inside the darkness of our body, a reed faraway from its origin that should go back to its roots.

\section{Comparative study of the subject}

Being familiar with theories in new psychology has a great effect on the literary criticism to such an extent that today there exist a psychological criticism. In this line of criticism a literary work can be analyzed from psychoanalytical view point in order to find new meaning and new understanding in a text. One aspect of this school of criticism is to look at a literary work from a nostalgic view point. Nostalgia in its general meaning can be a feeling of heartache or sorrow that claws at the soul, a sorrow that all human beings carry with themselves. For many years this feeling reflected in Persian poetry. Sorrow is tied historically to the poetry or at least to Persian poetry a connection as long as the history and poetry itself. There are scarcely any poet that didn't use nostalgia and its many aspects in their poems. It seems that what creates a poem and a lyric is sorrow and pain. In literature nostalgia is divided into personal and social nostalgia (Shamloo, 1996). Personal nostalgia can be caused by factors such as losing a family member or a loved one, imprisonment and exile, immigration, memories of childhood and youth, problems of old age and thinking about spiritual or psychological subjects. Based on what has been presented in this study examples of personal nostalgia in the works of Yushij and Abdel Muti Hijazi is going to be presented.

\section{MEthodology}

In this study "The Survey of Type of Works and Its Provisions" is used as ground for the psychological criticism of the works of Aminpour without psychoanalyzing the poet himself or looking for old pattern in his poetry. This study tries to explore and analyze the poet's "lifelong attachments" which manifested through different types of nostalgia and also shows the development of all kinds of nostalgia through his life. In literature nostalgia is a remembrance of sweet and forgotten past, remembrance of childhood and youth, simple rustic life and so on. The word nostalgia came from psychopathology and research conducted on this subject is the responsibility of psychological criticism, a branch of literary criticism. There are several ways that psychology can mix with art and literature, through the study of the process of creativity and creation of a work of art, through the survey of the genres and their provisions, through discussing artists and their life and personality and in the end through the study of the relationship between the reader and the work of art (Aminpour, 2005, p.137).

\section{Questions and Hypothesis}

1. What are the reasons for nostalgic tendencies in the works of Yushij and Hijazi?

2. What are the clearest signs of nostalgia in the works of these two poets?

3. What are the similarities and contrasts in the nostalgic or memorable components of their work?

The theory of this study is based on this assumption that the nostalgic element in the works of Yushij and Yusuf Hijazi are completely similar and there is minor contrast between them.

\section{RESULTS AND ANALYSIS}

\section{Nostalgia and a return to childhood}

One of the forms of personal nostalgia is remembering the memories of childhood and youth. Maybe it is not far from the truth to say each and every one of us feels a kind of sorrow when remembering our childhood and this fact that those days are long since passed. Yushij also, in some of his poems, remembers those simple and innocent times of purity with the same feeling of sorrow nostalgia. Those days that as he himself said in his book "Poems and Childhood" are the most poetic days of one's life and so are closer to the poet's heart. 
Alas, days of childhood past

No sorrow felt my heart ever

Simple mind, simple perception, less sorrow

Singing happily with other children

Happy days those days, happy days indeed

Ever remembered shall be those happy days

Those days are lost, gone those days

How we are going to be ever present? (Yushij, 1996, p.32).

Then the poet remembers those days that he played in the meadow with the lambs:

Here is where it all begins

Playing with the lambs

Looking at the clouds, flowers and hills

Listening to the bell sound of the herd

One with the whispers of the brook (ibid.)

For Yushij the woods and nature are the home because it is where he finds his childhood:

This here is my home

Belongs to my storytelling heart

This cursed heart of mine

Cost me my motherland

Here is the mark of my childhood (ibid.)

The opposition of the country life and urban life which is the opposition of natural, mythical and childish life versus the office life and industry and war inspires the poet and the artist to create a dream world. This is the dream that seems real to a child. Here, the poet, talking to his inner child, doesn't see this as a dream any more. This is not an unreachable dream any more.

Abdel Muti Hijazi also remembers his childhood and his village. His memories of his friends are evident through his poems:

Oh friends!

From my excessive fear of the road's end;

And from my fear of the night's arrival

"Farewell"

Painful it is to bid farewell and good night!

All words of bidding farewell is bitter

Death is bitter

And all things robs humans from the humans!

City streets are wide

They still in noon have all heat

That they absorbed in the noon.

Woe on the person who has not visited anyone except the sun;

Except buildings and its rail;

Except window displays and glasses.

Oh from the night of sky

From its off day;

It is empty from visiting.

Woe on somebody who does not love;

And all seasons his heart is winter.

Or later describes his memories of his nights out with his friends and their time together, remembering it all with a sigh:

Oh friends who are alive under solid walls;

Oh the star that remains sleepless at night;

I dread from the end of path,

I hope that it does not reach end;

And becomes narrow and threadlike;

And [this path] leave us sweet and pretty footprints

When there is no end for it

Like the horizon of countries at dawn;

Horizon in kind and warm countries

Crimson and tender dawn that embraces the houses [in the countires];

And trees in these villages are floating like the travelers' panniers.

I wish I were there

And move in its deep silence 
Its diluted and foggy light is the Island of life;

The heat of its field is flowing on water and does not bore its flow and current (p.69)

Each human being remembers his childhood differently. This difference is more obvious in the poetry of those poets with a sensitive nature. Childhood poetry in either case is affected by the bitter sweet memories of the poet's childhood. Childhood's memory with all its ups and downs has some similarities in the poetry of both the poets, talking about their dispossession, loneliness and suffering during childhood which has a more realistic and often dark hue. Talking about a child brings out those bitter memories of childhood. Although this word in the poem of Nazik Al-Malaika has a more optimistic and romantic atmosphere despite the poet's reputation as being a pessimist.

Yearning for a mythical and historical past

One of the concepts that captures the mind of a poet with religious belief is the creation and Adam's exile from heaven. Persian poets often talked about this topic in their poems remembering it with a feeling of sorrow and heartache Qeysar Aminpour also talks about this topic with the same feeling in two of his collections. Yushij (1996) uses the mythical factor to create a new world in order to show the pains and problems of the society in another light. That is why he uses the belief and collective unconscious of the ancient times to talk about new subjects. He uses different mythical background both nature myths and ancient also myths about animals and supernatural creatures.

In the poem The Phoenix, Yushij (1996) uses ancient myths. Phoenix in Roman language is a bird of various color that live a very long life. At the end of his life the bird gathers around a pile of firewood and sits on top singing a song so compelling that intoxicates even the bird himself and so he claps his wing together until the sparks coming from his wings set the pile afire that would burn the bird. Out of the ashes there would come an egg. The bird has no mate and it has been said that music is discovered out of his singing. Yushij looks at himself from this viewpoint. He sees himself as one that should carry a burden and finally burns in its fire so his offspring can be resurrected from the ashes and grow. He uses the phoenix as the symbol of resurrection:

Heavy wind blows the bird is burnt

The ashes has gathered up and discerned

That his hatchling will rise from the ashes (Yushij, 1996, p.174)

In Yushij poem animals are used as a kind of makeshift myth, created by his mind as the symbol of various beliefs in the society. Tree frog that predicts the rain, turtle that is the symbol of laziness, passivity and dullness, bittern, the bird of sorrow, the became the poet's companion and can be the symbol of sympathetic people: "Yushij complains about his own loneliness and about not being understood by others. He means that no one pays attention to the one who shouts on the wall of this ruins" (Azimi, 2003, p.31). Yushij and this bird are one and the same. His attention to birds as mythical symbols comes from his fondness of birds which are plentiful in his region. He uses them as the symbol of social and intellectual difficulties.

Yushij is fully aware of the necessity of symbolism when talking about social subjects or hardships in the society and so he uses cultural belief and collective unconscious. He uses ancient myths, nature myths, myths about animals and supernatural creatures to talk about his notions. In addition to using classical myths he also creates new myths and symbols himself using natural phenomena which come directly from his own creative mind. He is known as the leader of new poetry (free verse). Because he grow up in the country and is very close to rustic life and nature he uses natural elements in his poetry, creating a new meaning in his poems. He also gave reality to surreal elements through his poems. He starts his life in the country and felt really close to natural elements, rivulets, blossom, birds, herds and shepherds and through personification formed an emotional bond with them.

There is a strong bond between mythology and the collective nostalgia. Some believe that mythology comes from mankind's pre-historic dreams. Most important parallel for us however is this, the race in pre-historic times makes its wishes into structures of fantasy. Which as myth reach over into the historical ages in the same way the individual in his pre-historic period makes structure of fantasy out of his wishes which persist as dreams in the historical period. So is the myth a retained fragment from the infantile psychic life of the race and the dream is the myth of the individual (Abraham, 1998). Examples of this collective nostalgia in Hijazi's poetry are his yearning for being open-eyed, for the era of consciousness, for fighting oppression and for demanding freedom in Egypt, Hijazi used wind symbol in this ode to portray the wretched condition of his country where colonizers didn't leave anything but destruction behind.

How these secluded beauties

That scattered on paths [they became common],

The police and culprits do not regard as permissible;

I have become ill and unable to answer these refugees' sweet and warm calls;

This is that unfertilizing wind;

During night will strike on my window;

Wild wings of rain will scream on me

And wind will resume its lament (Hijazi, 1997, p. 10).

Primitivism and having a nostalgic feeling toward past are undeniable characteristics of our society and culture. One can easily see the effect of this feeling in different historical periods. Literature as an artistic and cultural aspect of the society can perfectly reflect the belief and ideology of a nation. Although Terry Eagleton believes that: 
Literature, then, one might say, does not stand in some reflective, symmetrical, one-to one relation with its object. The object is deformed, refracted, dissolved-reproduced less in the sense that a mirror reproduces its object than, perhaps, in the way that a dramatic performance reproduces the dramatic text (Eagleton, 2004, 80)

But one cannot deny the direct relation between literature and society. In Hijazi's poetry also recurrence is the characteristic of the wind with its various representations in modern Arabic poetry. For Abdel Muti Hijazi the wind is the symbol of destruction, the way it blows and ravages plantation and frail houses.

\section{Homesickness}

The cases of homesickness can be divided into two groups: the first group can be called personal homesickness which includes people who are away from their home for any reason, this kind is being reflected in the poetry of Qeysar. The poet who is away from his home and country remembers them with heartache and sorrow. Yushij'other nostalgic poem is In Memory of My Motherland the poet here nostalgically adesses the mount Farakesh which is near Yush, the poet's home town. The poet talks to the mount Farakesh about the pain and problems of living in the city feeling heartache and sorrow away from his home. Azimi (2003) observes that this might be the same pain and sorrow that he talks about so often "the core of my poetry is sorrow" (p.794).

Oh thou Farakesh it's been two years

That away I am from your pleasant sight

Mine is not my heart, flies away to you

So much that I long to see you

I, a captive, in these city rooms

Like a bird in a cage

A thief I am, as it seems

Deserving such prison (Yushji, 1996, p. 108)

And again in the poem "surrendered":

Odd I became and surrendered

Like a twig on the waves

My leaves all fallen

In the midst of the vortex

Leaving me just odd (p. 111).

In the end the poet complains about homesickness and wishes to be in his own motherland:

My eyes looking everywhere, my thoughts on home

Even the sea talks about my sorrow...

Until the day I pass you by again

Wish I was in my motherland, oh I wish I was in my motherland (p.159).

Hijazi (1997) through comparing the people who live in the city with those who live in the country reaches this conclusion that simplicity is the characteristic of rustic life "people in metropolitans are numbers" (p.12) in this case like using the train of The Little Prince's thoughts he considers the people in the country as being simple and having the honesty of children while the people of the city are like Grownups. Hijazi uses the lemon metaphor as a mask for the poet and talks about returning to the nature and spirited life also about running away from the burdensome life of the city that prevent us from fulfilling our dreams in spite of the fast pace of life:

The lemon basket left the village early in the morning,

Until that time, it was not cursed.

It was green and humid with dews;

[And used to] float in the shadow currents;

In its siesta, it was the bride of birds.

Oh who did bestow on him beauty and tenderness?

Which hands did came to pick that [lemon] in the morning?

And who did carry him in the twilight,

And take here to busy streets?

Where steps do not stop, oh cars!

The cars which move with gas.

Miserable is one who does not smell you!

And the sun will dry your moisture.

(Hijazi, 1997, p.250).

In the beginning of the ode it seems that the poet is talking to the lemon which is ripe on the tree until it's been picked by the hand of a cruel man and been taken to the city against its will. In the city the lemon suffers hardship, bitter fate and abjection, sitting in front of the shop without a customer under the burning sun that scorches its freshness until it shrivels. It is the assumed meaning of the poem while the poet is in fact the lemon, force migrated to the city against his own will, to earn money for his material needs, so he sympathizes with the bitter fate of the lemon and reaches to this conclusion that the life in the city is different that the life in the country which is close to his heart. There is human relation, purity and sheer happiness in the country life that there is no trace of it in the city. 


\section{Nostalgia of Death}

Each culture and civilization has certain beliefs about death which through history has engaged the mind of the human beings. Mankind have talked about death for ages in different forms and expressed their different viewpoints. Here, the viewpoint and feeling of poets can be interesting because they talk about their surroundings through their emotions. The obligation of the modern poetry is to reflect the concerns of humanity and in the matter of life and death it reflects the human intellect and literary achievements. Sometimes in the poetry of Yushij the subject of death becomes extremely sad, filling the poet with heavy grief. Looking closely at his elegies shows this point perfectly. The poem called My Father is one such poem that supports this bitter attitude toward death:

Covered up and lightly he is gone

So to wear me out by his grief (p. 351)

Or condemning the death that is the result of human's criminal acts:

Children, women

Men, those who were home

My friends, my fellows, all murdered right at this moment (p. 773)

Yushij (1996) tries to portray life in a society that humans suffer to liberate themselves and others from manacles and chains. He as a warrior goes to arena shouting. Somewhere in the poem The Phoenix the representation of the life giving power of death, a story told and retold times and again, brings the message of sacrifice and rebirth. Along with this image a revolution happens and heroes, giving their life, define death as a wakeup call, a power that opens the eye and let the life continues:

The city is wide awake

The city is vigilant

Blinking, he has to go

And his eyes

Has to pass over the world (p. 694).

Yushij has grew up in a religious atmosphere and Islam in general is against living in abjection that is why Yushij prefers a bloody death instead of a life time of abjection because Such death creates a movement. Thoughts like this keep coming to Yushij' mind along with a feeling of sorrow and nostalgia.

Abdel Muti Hijazi in the ode called Bagdad and Death talks about death, despair and disappointment and how the shadow of death is spread all over the city. Here Bagdad is the representation of the memories of past in the life of the poet:

Oh Baghdad!

Your murdered child is under sands

And waiting for you to write doomsday history with your axe!

Death is not to be buried under ground;

And life is not to walk on it (p.700).

In the following lines of the same ode the poet talks about the child of Bagdad in despair. That can't close his eyes even for a second and cries about his wounds. That is how the poet with a soul full of agony and suffering talks about his pure emotions and feelings.

\section{Utopian Nostalgia}

Utopia is a lifelong dream of scholars and philosophers. Sometimes philosophers like Plato talk about characteristics of utopia and sometimes poets and artists like Saadi talk about its traits. In any case it seems that longing for utopia always weighted on the mind of the artists and philosophers the same. Yushij's long poem Manelli is also the story of a fisherman called Manelli that one night like other nights goes to the sea for fishing but a little later as a great storm rises right of the middle of the waves comes a mermaid. She asks him to go with her to the depth of the sea. The fisherman refuses at first but after a long argument and much persuasion loses his heart and intoxicated falls to the arms of the mermaid going to the depth of the sea with her. After spending a night with her he gets back to the shore in the morning. Upon his return he finds everything different. He can't find his home and roam about in confusion. Not knowing where to go his mind keep coming back to the sea where his heart desires. Yushij himself talks about the poem,

But basically the story has some differences with other versions in world literature. I am not the first to talk about mermaids... I just tried to give her flesh and blood in my own imagination. I made this story about 1945 more or less. About two or three years ago before one of my friend translates Urashima. The thing that I used most was the theme or the concept of the story. I thought about my own obligation in this matter. This in fact is my answer to my friend's Urashima on a conceptual level (Yushij, 1996, 350).

Manelli in fact is Yushij himself, Roxana the narrator is the poet as well. Manelli talks about his own difficulties with the mermaid:

And for such worthless bread

I wasted away all of my life

There is none more needy than me

In a world that one should live on his own blood money

...the floods of sweat wasted away my brow 
My labors shriveled me bald

Death knocks me to the wall every day (Yushij, 1996, p.359).

Yushij's description of the sea -utopia- is very beautiful. He tells it all through the mermaid but in fact these are his own thoughts and words. The mermaid promises him a life of happiness and comfort under the sea:

True, for everything good on earth

There are thing better under the sea

... and for every flower there are corals

I can do it all you'll see

All that passes on your mind

There are beauties all but spirit

Dizzy from dancing

Birds singing all the time

From the comfort of their pale beak

From their long and narrow pecker

Comes a song, a lyric

Such orphic flowers

Changing color at every laugh

That if you but once smell their scent

You will be intoxicated for life

Oh if you just know how lucky you are

More than the others

Are lucky those

Who live under the sea (Yushij, 1996, pp. 368).

That utopia which Yushij creates in the Manelli, is it the same surreal world, the same paradise lost that symbolists try to create and induce on our minds. The same hidden world beyond the reality that only the poet, using his psychic power bestowed upon him, can tell us about. Maybe this is the same way that enables Yushij to meet the mermaid -the spirit of the see and the utopia- the being that not everybody is able to see as the mermaid herself tell us:

Not all the people you poor man

Are able to see me as you did

Or be with me this easily as you did (p. 357).

Yushij, so far away from such despairs, reaches the utopia, those glorious cities -based on symbolists' viewpoint- in the arms of the mermaid. He with his description tries to create and presents a new world beyond reality. A place to be liberated from pain and bitterness and failure of this world, to reach the lifelong dream of mankind. That utopia that Yushij and Shamloo created in their poetry is very similar to the surreal world created by symbolist poets in $19^{\text {th }}$ century French through using the tangible and symbolic elements in their poetry. That's why it is so close to symbolism that tries to create a utopia beyond the reality. Other examples of Yushij's nostalgic poems that uses the theme of homesickness includes the collections Oh You Yeoman, My Delight, and Daybreak.

The utopian literature in fact is distinguished from other genres by its idealism. Sometimes it is deliberately unattainable and unreal and sometimes it shows an ideal state that can be presented as a cultural standard. These two types of idealism in utopian literature leads to the creation of two types of utopian worlds: a world that shows an inconceivable utopia -a Neverland - (dystopia) or a supreme world that is in fact attainable (utopia). Believing in such imaginary world that all humanity dreams seems possible is the reason behind the creation of many works with such theme since the ancient times. The collection of these works is called utopian literature. The creation of such place in our world of imagination -a place that exist (in our mind) and doesn't exist (in reality) at the same time- in any concept, has risen out of our ideal and imagination. That is why there is no division between literary genre in this subcategory and any text in any area of philosophy, literature, religion and such, written about or with the theme of utopia, is categorized under utopian literature. Abdel Muti Hijazi in many of his odes talks about his own concerns with utopia and tells it though his own sweet poems. One of the most clear of them all is the ode, The journey Began which talks about the memory of Abdel Naser who was the symbol of freedom and generosity. Hijazi talks about how he fought the oppression and tyranny of the colonizers and in the midst of it all he relates him to the Hegira of Prophet Mohammad and presents Abdel Naser as the only salvation for the Arab nation to be free from the oppression and injustice, to finally attain justice and their long ignored rights.

It's been said before that the basis of decline in human values lies in the opposition between tradition and modernity. Humanity is been forgotten in the midst of an era of rumble, metal and rapid pace of life. In Romanticism we can see a return to the past, a revival of tradition and old values, a criticism of and a rebellion against the capitalism and the modern industrial world. Hijazi also talks about a city full of happiness and bliss that is been destroyed by abjection and fowl modernity.

\section{CONCLUSION}


Nostalgia is a modern psychological phenomenon reflecting differently through the poetry of modern poets. Longing for past yearning for a past long gone are characteristics of the poetry of Yushij and Abdel Muti Hijazi. Poets who clearly show both lyrical Romanticism and social Romanticism though their poetry. Yearning for the past (nostalgia) is one of the widely used theme in the Persian and Arabic modern poetry so nostalgia has an important place in both Romantic and social-political poetry of both poets. City in the poetry of those poets who migrated or exiled is the symbol of alienation, chaos and confusion. In comparison the nature is the symbol of motherland and peace. Abdel Muti Hijazi, as a poet, values these symbols in his poems. For him the country is the symbol of intimacy, sympathy, emotional stability, friend and family. He migrated from rustic life and suddenly finds himself facing the cruelty of the city. The city that is the symbol of loneliness, alienation, decay, heartlessness, indifference and instability. In another poem Hijazi is at war with the city and can't ignore its vices, but finds himself getting used to living in the city and became one of them. Now the city seems interesting and attractive in his eyes and at the end looks like the symbol of motherland and even Arabic nation and their alliance. A desire for the past that can be equal to yearning is a natural common feeling that happens to all of us unconsciously. Remembering the past entice us to write and compose. That is why nostalgia is related to memories. These pieces often have a fervid and regretful taste. For Yushij home is where he was born. Every time he is tired of living in the city or barely endures it, he remembers life in his village, the woods and mountains with a feeling of sorrow. Naturalism in the free verse Persian poetry starts with Yushij and his keen interest in visual and tangible aspects of life. Yushij tried to portray a just image of the natural and social atmosphere of his own time through his poetry of free verse. The main theme of his poems is remembering childhood memories, elegy on homesickness and seeking a utopia.

\section{REFERENCES}

[1] Abraham, K. (1913). Dreams and myths: A study in race psychology. New York: Nervous and Mental Disease Publication.

[2] Aminpour, Q. (2005). Tradition and Innovation in Modern Poetry. Tehran: Science and Culture Press.

[3] Azimi, M. (2003). An exploration in the poetry of Nima. Sari: Zavash.

[4] Dastgheib, A. (1994). Looking at Mahdi Akhavan-Sales. Tehram: Morvarid

[5] Eagleton, T. (2002). Marxism and literary criticism. London: Psychology Press.

[6] Hamidian, S. (2004). Story of Metamorphosis: the process of transformation in the petry of Nima Yushij. Tehran: Niloofar Press.

[7] Hijazi, A. (1993). Complete Poems. Kuwait: Dar Al Saad Al Sabah.

[8] Hijazi, A. (1978). Kingdom of Night Objects. Beirut: Dar Al Adab.

[9] Lowy, M., \& Sayre, R. (2001). Romanticism against the Tide of Modernity. London: Duke University Press.

[10] Seyed Hosseini, R. (1987). Literary Movements. Tehran: Nile.

[11] Shamloo, S. (1996). Psychopathology. Tehran: Roshd.

[12] Sharifian, Mahdi. (2008). "Examining the Procedure of Nostalgia in the Poems of Akhavan-Sales: series of articles on modern literature, mirror in front of poetry, Abbas Ali Vafaee." Tehran, Sokhan.

[13] Yushij, Nima (1996). Nima Yushji’s Poetry. Tehran. Nilofar.

Naser Ghasemi Rozveh was born in Isfahan. He got his M. A. degree in Arabic Literature from Tehran University in 2005. In 2011 he received his Ph. D. in Arabic Literature from Damascus University. Currently his is a faculty member in University of Tehran. His area of interest is Persian and Arabic literature as well as studies in comparative literature.

Zeynolabedin Faramarzi was born in Golestan Province. He obtained his M.A. degree in Arabic Literature from Tehran University in 2005. In 2009 he gained his Ph.D. in Arabic Literature from Ferdowsi University of Mashhad. Currently he is a faulty member in Gonbad Kavous University in Golestan Province. His area of interest is both Persian and Arabic literature as well as studies in comparative literature. 